University of Nebraska - Lincoln

DigitalCommons@University of Nebraska - Lincoln

Faculty Papers and Publications in Animal

Science

Animal Science Department

January 1982

BREED COMPARISONS FOR AGE AND WEIGHT AT PUBERTY IN

GILTS

L. K. Hutchens

Oklahoma State University, Stillwater

R. L. Hintz

Oklahoma State University, Stillwater

R. K. Johnson

University of Nebraska-Lincoln, rjohnson5@unl.edu

Follow this and additional works at: https://digitalcommons.unl.edu/animalscifacpub

Part of the Animal Sciences Commons

Hutchens, L. K.; Hintz, R. L.; and Johnson, R. K., "BREED COMPARISONS FOR AGE AND WEIGHT AT

PUBERTY IN GILTS" (1982). Faculty Papers and Publications in Animal Science. 23.

https://digitalcommons.unl.edu/animalscifacpub/23

This Article is brought to you for free and open access by the Animal Science Department at DigitalCommons@University of Nebraska - Lincoln. It has been accepted for inclusion in Faculty Papers and Publications in Animal Science by an authorized administrator of DigitalCommons@University of Nebraska - Lincoln. 


\title{
BREED COMPARISONS FOR AGE AND WEIGHT AT PUBERTY IN GILTS ${ }^{1}$
}

\author{
L. K. Hutchens ${ }^{2}$, R. L. Hintz ${ }^{2}$ and R. K. Johnson ${ }^{3}$ \\ Oklahoma State University, Stillwater 74078
}

\begin{abstract}
Summary
Data on 213 purebred and 524 crossbred gilts produced in a four-breed diallel crossing design involving the Duroc (D), Yorkshire (Y), Landrace (L) and Spotted (S) breeds were analyzed for age and weight at puberty. The breed of sire $x$ breed of dam interaction was significant for both age and weight at puberty. However, differences among reciprocals were not significant, and thus, reciprocal means were combined. Crossbreds were younger ( $7.9 \mathrm{~d}$ ) and heavier $(1.2 \mathrm{~kg})$ at puberty than purebreds. Significant heterosis for age at puberty was found for $D \times L(-14.3 \mathrm{~d}), S \times D(-12.8 \mathrm{~d})$ and $S \times L(-9.0 \mathrm{~d})$ crosses. No significant heterosis was found in $\mathrm{L} \times \mathrm{Y}, \mathrm{S} \times \mathrm{Y}$ and $D \times L$ crosses. The only crossbred group that exhibited significant heterosis for weight at puberty was the $\mathrm{L} \times \mathrm{Y}(4.5 \mathrm{~kg})$. The oldest breed groups at puberty were the $D$ and $Y$, while the youngest were all possible two-breed crosses involving $\mathrm{D}, \mathrm{S}$ and $\mathrm{L}$. Few differences were observed among breed groups in weight at puberty, however, the $\mathrm{D} \times \mathrm{Y}$ was significantly heavier than the $\mathrm{L}, \mathrm{Y}, \mathrm{S} \times \mathrm{L}$ and $\mathrm{D} \times \mathrm{L}$.

(Key Words: Swine, Breeds, Crossbreds, Heterosis, Puberty.)

\section{Introduction}

A reduction in the age when gilts are bred, without any significant reduction in their performance, can result in savings of both fixed and variable costs. Environmental factors such as type of housing, daily exposure of gilts to

\footnotetext{
'Journal Article 3993 of the Agr. Exp. Sta., Oklahome State Univ., Stillwater 74078.

${ }^{2}$ Anim. Sci. Dept.

${ }^{3}$ Present address: Anim. Sci. Dept., Univ. of
} Nebraska, Lincoln 68583.
\end{abstract}

boars, season of birth, group size and possibly the moving and mixing of gilts can affect age at puberty (Hughes and Cole, 1976; Mavrogenis and Robison, 1976; Zimmerman et al., 1976; Christenson, 1979).

Little information is available regarding breed differences in, and heterosis effects on, age and weight at puberty. Therefore, the objective of this study was to compare purebreds and crossbreds of Duroc, Yorkshire, Landrace and Spotted breeding for age and weight at puberty. Knowledge of breed differences in pubertal characteristics and other biologically important traits will be helpful in the identification of mating systems that maximize total production efficiency under specifically designed management systems.

\section{Materials and Methods}

In spring 1976, 25 gilts and four boars for each of the Landrace and Spotted breeds were purchased from breeders and used to establish herds. A broad genetic base for the Duroc and Yorkshire breeds had been maintained for several years, primarily by the purchase of boars from performance testing stations throughout the United States. To sample and maintain a broad genetic base in all four breeds, we replaced one or more boars of each breed each season. Seven to nine boars and 30 to 35 females/breed were used.

Gilts were produced from a four breed diallel mating system involving the Duroc, Yorkshire, Spotted and Landrace breeds. Boars were randomly mated to at least one dam of each breed. The data were derived from gilts born during four consecutive (fall and spring) farrowing seasons beginning in the fall of 1976 . Of the 819 gilts available, 82 were never observed in estrus (estrous detection was discontinued each season when the youngest gilt was at least $219 \mathrm{~d}$ of age), and those 737 gilts 
which expressed estrus were used in the analyses (table 1 ). Based on $\chi^{2}$ tests, the percentage of gilts not observed in estrus was significantly higher in purebreds (16.4\%) than in crossbreds (7.8\%) and significantly higher in Duroc purebreds compared to other breed groups.

The sires selected from each breed were chosen on the basis of the National Swine Improvement Federation Test station index of growth and backfat (Hubbard, 1976). Replacement gilts were selected within herd, on the basis of a similar index. Each season, females of each breed were assigned to a sire at random.

Females were hand-mated during an 8-wk breeding season and pasture-fed 1.8 to $2.2 \mathrm{~kg}$ of a $15 \%$ protein corn- or milo-based diet. Spring litters were farrowed during March and April, and fall litters during September and October. Sows were farrowed in a central confinement building. One to $2 \mathrm{wk}$ later, sows were moved to either sheltered pasture lots with three to four litters/lot or to an open-front confinement building with one litter/pen. Creep feed was made available at 3-wk of age and litters were weaned at 6-wk. At approximately 8-wk of age, gilts were randomly allotted within litter to be fed in an open-front confinement building (10 gilts/pen) adjacent to at least one pen of littermate boars or in pasture lots (approximately 50/lot) along with littermate barrows.

All gilts were fed a $14 \%$ protein corn- or milo-based diet. Gilts were removed from test weekly at approximately $90.7 \mathrm{~kg}$. Then, gilts were probed for backfat, placed together in pasture lots and fed daily 1.8 to $2.2 \mathrm{~kg}$ of a $15 \%$ protein diet. Estrous detection was started after gilts reached $90.7 \mathrm{~kg}$ so that measurements of backfat at $90.7 \mathrm{~kg}$, days to $90.7 \mathrm{~kg}$ and rate of gain during the gain test could be obtained. The gain test data on the gilts were needed to estimate phenotypic and genetic correlations between growth traits and age at puberty and weight at puberty (Hutchens et al., 1981). Estrous detection was done daily with "teaser" boars. The maximum numbers of gilts/lot was held to about 30, and "teaser" boars were kept in the lots 15 to $30 \mathrm{~min}$ to provide uniform stimulation. The placement of the gilt and boar lots was such that a "lane" of about $7.62 \mathrm{~m}$ separated the lots. Therefore, some degree of visual, auditory and olfactory stimulation was available continuously.

Puberty was defined as the first detectable estrus as indicated by a standing response to a teaser boar. The average age when estrous detection began ranged from 163.5 to $172.9 \mathrm{~d}$ for the various breed groups. The distribution of age at puberty approximated a normal distribution because $66.4,95.1$ and $99.6 \%$ of the records were within 1,2 and 3 standard deviations of the overall mean, respectively, and $47.5 \%$ of the records were above the mean. For weight at puberty, $44.6 \%$ of the records were above the mean and $68.5,94.8$ and $98.2 \%$ of the reocrds were within 1,2 and 3 standard deviations of the mean. Estrous detection was continued each season until the youngest gilt was at least $219 \mathrm{~d}$ of age. The $219 \mathrm{~d}$ of age was dictated by the need to provide space in the swine facilities for the next set of pigs. Any gilts that displayed obvious signs of disease or lameness were omitted from the analysis.

TABLE 1. NUMBER OF GILTS PER BREED GROUPa

\begin{tabular}{llllr}
\hline & \multicolumn{3}{c}{ Breed of dam } \\
\cline { 2 - 5 } Breed of sire & $\mathrm{D}$ & $\mathrm{Y}$ & $\mathrm{L}$ & $\mathrm{S}$ \\
\hline Duroc (D) & $62(19)^{\mathrm{b}}$ & $45(4)$ & $60(6)$ & $48(0)$ \\
Yorkshire (Y) & $52(5)$ & $42(8)$ & $53(7)$ & $47(4)$ \\
Landrace (L) & $48(3)$ & $44(5)$ & $59(5)$ & $45(2)$ \\
Spotted (S) & $51(0)$ & $58(7)$ & $55(4)$ & $50(3)$ \\
\hline
\end{tabular}

\footnotetext{
a Total number of gilts produced during fall 1976, spring 1977 , fall 1977 and spring 1978 farrowing seasons.

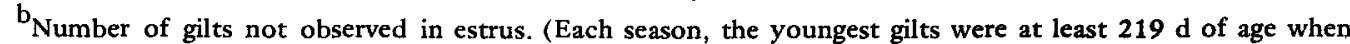
estrous detection was terminated.)
} 
The following linear model was assumed for age at puberty and weight at puberty:

$$
\mathbf{Y}=\mathbf{X} \beta+\mathbf{Z}_{1} \mathbf{s}+\mathbf{Z}_{2} \mathbf{d}+\mathbf{e},
$$

where

$\mathbf{Y}$ is an observation vector,

$\mathbf{X}$ is a known design matrix of fixed effects,

$\beta$ is an unknown vector of fixed effects [all levels of breed of sire (BOS), breed of dam (BOD), season of birth (SEA), management during gain test (MGT), year of birth (YR) with year being defined as two consecutive fall and spring farrowing seasons, YR $\times$ SEA, MGT $\times$ BOS, MGT $\times$ BOD, YR $\times$ BOS, YR $\times$ BOD, BOS $\times$ BOD, BOS $\times$ BOD $\times$ MGT, BOS $\times$ BOD $X$ YR and a common constant mean $\mu$ ],

$Z_{1}$ is a known design matrix for sires,

$Z_{2}$ is a known design matrix for dams,

$s$ is a random vector of one-half the additive genetic effect of the sires having a multivariate distribution with mean zero and a nonsingular variance-covariance matrix $\mathbf{I} \sigma_{\mathrm{s}}{ }^{2}$, where $\sigma_{\mathrm{s}}{ }^{2}$ is equal to one-fourth the additive genetic variance,

d is a random vector of one-half the additive genetic effects and any material effects of the dam having a multivariate distribution with mean zero and a nonsingular variance-covariance matrix $I \sigma_{\mathrm{d}}{ }^{2}$, where $\sigma_{\mathrm{d}}{ }^{2}$ is equal to one-fourth the additive genetic variance plus any maternal variation,

$\mathbf{e}$ is a random vector of residual effects including environmental and other genetic effects having a multivariate distribution with mean zero and a nonsingular variance-covariance matrix $I \sigma_{\mathrm{e}}{ }^{2}$ and $s$, d and e are mutally uncorrelated.

The criteria used for determining interactions to include in the model were results of preliminary least-square analysis. Furthermore, inclusion of all possible interactions would have created a sparce matrix.

If variance ratios are known for the class of linear models assumed and assumptions made, the solutions $\hat{\beta}$ are generalized least-square estimates of functions of the fixed effects (Henderson et al., 1959; Henderson, 1973), and solutions $\hat{\mathbf{s}}$ and $\hat{\mathbf{d}}$ are best linear unbiased predictors (BLUP) of the random effects (Henderson, 1963,1973 ) for sire and dam, respectively, of the mixed model equations. Although the variance ratios are never really known, estimates of these ratios can be obtained from variance components or heritability estimates reported in the literature. Few estimates were available in the literature for these traits. Both maternal and paternal half-sib heritability estimates obtained from these data were used (Hutchens et al., 1981).

The last equation within each fixed class was set to zero to obtain a nonsingular matrix. The dam equations were absorbed to save computer time and to obtain a direct inverse.

Differences in reductions due to fitting different models were used to determine which fixed effects explained a significant portion of the variation in age and weight at puberty. Differences among means were tested by Tukey's hsd procedure. The tests of significance were not exact tests since estimates of the variance ratios were used in the mixed equations. Computer programs developed by $\mathbf{R}$. $\mathbf{L}$. Hintz (unpublished data) were used to perform the analysis.

\section{Results and Discussion}

Analysis of Variance. The year $x$ season interaction was a significant source of variation in age and weight at puberty (table 2). Springborn gilts were $6.4 \mathrm{~d}$ younger at puberty than fall born gilts in yr 1 and $15.3 \mathrm{~d}$ younger in $\mathrm{yr}$ 2. These results indicate that spring-born gilts would be expected to reach puberty at younger ages. Spring-born gilts were $3.7 \mathrm{~kg}$ heavier than fall born gilts in $\mathrm{yr} 1$ and $2.6 \mathrm{~kg}$ lighter in weight in yr 2.

Gilts reared in confinement adjacent to boars of a similar age were significantly younger at puberty $(5.5 \mathrm{~d})$ than gilts reared on pasture with barrows. This difference may be attributed partly to the fact that gilts in confinement grew faster and thus were 5.7 younger when exposed to boars for estrous detection.

A significant interaction between management system and season affected weight at puberty. Weight at puberty was similar for fallborn gilts, regardless of management. However, spring-born gilts reared in confinement were $3.9 \mathrm{~kg}$ lighter in weight at puberty than pasturereared gilts. These results may have been due to possible environmental differences. Gilts reared in confinement and exposed to boars on pastures in the fall (spring born) may have been experiencing "stress", resulting in the lower mean weight at puberty. 
TABLE 2. MEAN SQUARES AND TEST OF SIGNIFICANCE FOR FIXED EFFECTS FOR PUBERTAL TRAITS

\begin{tabular}{lccc}
\hline & & & Trait \\
Source & & Age & Weight \\
at puberty & at puberty \\
\hline Breed of sire (BOS) & df & 218.28 & $287^{*} .28^{*}$ \\
Breed of dam (BOD) & 3 & $1,356.52^{*}$ & 69.78 \\
Season (SEA) & 3 & $14,950.40^{* *}$ & 161.78 \\
Management (MGT) & 1 & $4,809.22^{*}$ & $764.03^{* *}$ \\
Year (YR) & 1 & 58.20 & $1,443.86^{* *}$ \\
YR X SEA & 1 & $2,616.15^{*}$ & $1,290.72^{* *}$ \\
MGT X SEA & 1 & 266.51 & $473.72^{*}$ \\
MGT X BOS & 1 & 850.56 & 105.32 \\
MGT X BOD & 3 & 342.47 & 108.56 \\
YR X BOS & 3 & 270.69 & 145.88 \\
YR X BOD & 3 & 512.22 & 136.53 \\
BOS X BOD & 3 & $1,773.27^{* *}$ & $204.37^{*}$ \\
BOS X BOD X MGT & 9 & 556.47 & 75.40 \\
BOS X BOD X YR & 9 & 368.93 & 115.28 \\
BOS X BOD X SEA & 9 & 327.89 & 49.89 \\
Error & 9 & 395.47 & 84.05 \\
\hline
\end{tabular}

$* \mathrm{P}<.05$.

$* * \mathrm{P}<.01$.

The breed of sire $x$ breed of dam interaction explained a significant amount of variation in both age and weight at puberty. Two possible causes for this interaction are heterosis and reciprocal differences.

Heterosis. Crossbred gilts were $7.9 \mathrm{~d}$ younger at puberty than purebred gilts (table 3 ). Since estrous detection was started when gilts attained a constant weight and was discontinued when the youngest gilt was $219 \mathrm{~d}$ of age, certain biases may have existed. Crossbred gilts grew faster and thus were exposed to boars at

TABLE 3. INDIVIDUAL HETEROSIS OF CROSSBRED GILTS FOR PUBERTAL TRAITS

\begin{tabular}{|c|c|c|c|c|c|c|}
\hline \multirow[b]{2}{*}{ Contrast $^{\mathbf{a}}$} & \multicolumn{3}{|c|}{$\begin{array}{l}\text { Age at puberty } \\
\text { (d) }\end{array}$} & \multicolumn{3}{|c|}{$\begin{array}{c}\text { Weight at puberty } \\
(\mathrm{kg})\end{array}$} \\
\hline & $\begin{array}{l}\text { Differ- } \\
\text { ence }\end{array}$ & $\%$ & $\mathrm{SE}^{\mathrm{C}}$ & $\begin{array}{l}\text { Differ- } \\
\text { ence }\end{array}$ & $\%$ & $\mathrm{SE}^{\mathrm{c}}$ \\
\hline $1 / 2[(D S+S D)-(D D+S S)]$ & $-12.8^{* *}$ & 6.5 & 3.4 & 1.6 & 1.7 & 1.5 \\
\hline $1 / 2[(D Y+Y D)-(D D+Y Y)]$ & -2.8 & 1.4 & 4.7 & 3.9 & 4.2 & 2.1 \\
\hline $1 / 2[(\mathbf{D L}+\mathrm{LD})-(\mathrm{DD}+\mathrm{LL})]$ & $-14.3^{* *}$ & 7.2 & 3.3 & -2.2 & 2.3 & 1.5 \\
\hline $1 / 2[(S Y+Y S)-(S S+Y Y)]$ & -7.5 & 3.8 & 4.8 & 2.1 & 2.2 & 2.2 \\
\hline $1 / 2[(S L+L S)-(S S+L L)]$ & $-9.0^{* *}$ & 4.6 & 3.3 & .4 & .4 & 1.5 \\
\hline $1 / 2[(Y L+L Y)-(Y Y+L L)]$ & -.7 & .3 & 3.6 & $4.5^{*}$ & 4.9 & 1.6 \\
\hline Crossbred-purebred $\mathrm{b}$ & $-7.9 * *$ & & 2.0 & 1.2 & & .9 \\
\hline
\end{tabular}

${ }^{a} \mathrm{D}=$ Duroc, $\mathrm{L}=$ Landrace, $\mathrm{S}=$ Spotted and $\mathrm{Y}=$ Yorkshire ; breed of sire listed first.

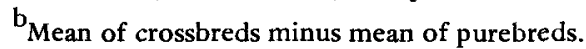

${ }^{c}$ Standard error of the difference between means.

${ }^{*} \mathrm{P}<.05$.

${ }^{* *} \mathrm{P}<.01$. 
an earlier age. Consequently, it was possible for crossbred gilts to be detected in estrus at a younger age. In addition, among those gilts that had not been detected in estrus at the end of each season, a much larger percentage was purebred (11.4 vs $7.8 \%$ ). Thus, assuming that many of these gilts would eventually exhibit estrus, the heterotic advantage for age at puberty may have been underestimated.

All crosses had an advantage over their respective purebred averages in age at puberty. This advantage was significant for all crossbred groups except the Duroc-Yorkshire and Yorkshire-Landrace crosses. The largest heterosis advantage in age at puberty was $14.3 \mathrm{~d}$ (7.2\%) for the Duroc-Landrace cross.

Few investigations have been made with the same breed combinations that were used in this study; however, the heterosis advantage observed in other studies generally has been larger. A comparison of Duroc, Yorkshire and Poland China purebreds and crossbreds showed a crossbred advantage of $27 \mathrm{~d}$ (Foote et al., 1956). Comparisons involving Poland-Chinas crossed with Chester Whites (Zimmerman et al., 1960) and Poland-Chinas crossed with Yorkshire (Clark et al., 1970) demonstrated 21.7 and 14.0 d advantage, respectively, for crossbred gilts. However, only a $4.3 \mathrm{~d}$ advantage for crossbreds was observed in a study involving Yorkshire and Durocs (Short, 1963).

Generally, crossbreds were heavier at puberty than their respective purebred averages $(1.2 \mathrm{~kg})$; the Duroc-Landrace, however, was 2.2 $\mathrm{kg}$ lighter in weight. The only crossbred group exhibiting significant heterosis for weight at puberty was the Landrace-Yorkshire, which was $4.5 \mathrm{~kg}(4.9 \%)$ heavier. Duroc-Yorkshire crosses were reported to be $4.2 \mathrm{~kg}$ heavier at puberty than their respective purebreds (Short, 1963); this difference is similar to the $3.9 \mathrm{~kg}(4.2 \%)$ advantage observed for the Duroc-Yorkshire crosses in this study.

Reciprocal Differences. Differences between reciprocals might be expected to be due primarily to maternal genetic differences or to an interaction between maternal and direct genetic effects. Maternal genetic effects have been suggested based on expectations of variance components (Reutzel and Sumption, 1968; Legault, 1973; Hutchens et al., 1981). A comparison among the reciprocal breed crosses indicated no significant differences among any of the reciprocals for either age or weight at puberty.

Investigations of reciprocal differences in pubertal characteristics of swine are limited. Foote et al. (1956) found a significant difference among Duroc-Yorkshire reciprocals in age at puberty. However, no significant difference in age at puberty was found between YorkshirePoland China reciprocals (Clark et al., 1970) or between Yorkshire-Duroc reciprocals (Short, 1963).

Since no significant reciprocal differences

TABLE 4. ADJUSTED BREED GROUP MEANS AS DEVIATIONS FROM THE YORKSHIRE PUREBRED MEAN ${ }^{a}$

\begin{tabular}{lcc}
$\begin{array}{l}\text { Breed } \\
\text { groupb }\end{array}$ & $\begin{array}{l}\text { Age } \\
\text { at puberty, d }\end{array}$ & $\begin{array}{l}\text { Weight } \\
\text { at puberty, kg }\end{array}$ \\
\hline Duroc & $2.3 \pm 4.1^{\mathrm{d}}$ & $6.6 \pm 2.0^{\mathrm{de}}$ \\
Spotted & $-4.6 \pm 3.9^{\mathrm{defg}}$ & $2.2 \pm 1.9^{\mathrm{de}}$ \\
Yorkshire & $.0 \pm 4.6^{\mathrm{defg}}$ & $.0 \pm 2.2^{\mathrm{d}}$ \\
Landrace & $-4.4 \pm 3.9^{\mathrm{defg}}$ & $-1.3 \pm 1.9^{\mathrm{d}}$ \\
D.Sc & $-13.9 \pm 2.8^{\mathrm{ef}}$ & $2.8 \pm 1.3^{\mathrm{de}}$ \\
D.Y & $-1.7 \pm 2.9^{\mathrm{dg}}$ & $7.3 \pm 1.4^{\mathrm{e}}$ \\
D.L & $-15.4 \pm 2.8^{\mathrm{e}}$ & $.5 \pm 1.4^{\mathrm{d}}$ \\
S.Y & $-9.8 \pm 2.8^{\mathrm{defg}}$ & $3.2 \pm 1.4^{\mathrm{de}}$ \\
S.L & $-13.5 \pm 2.9 \mathrm{eg}$ & $.8 \pm 1.4^{\mathrm{d}}$ \\
Y.L & $-2.9 \pm 3.0^{\mathrm{dfg}}$ & $3.8 \pm 1.5^{\mathrm{de}}$ \\
\hline
\end{tabular}

\footnotetext{
${ }^{\mathrm{a}}$ Yorkshire purebred adjusted mean $=198.9 \mathrm{~d}$ and $90.9 \mathrm{~kg}$.

$\mathrm{b}_{\mathrm{D}}=$ Duroc, $\mathrm{L}=$ Landrace, $\mathrm{S}=$ Spotted and $\mathrm{Y}=$ Yorkshire.

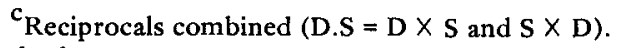

$\mathrm{d}, \mathrm{e}, \mathrm{f}, \mathrm{g}_{\mathrm{Means}}$ in the same column with no common superscripts differ $(\mathrm{P}<.05)$.
} 
were found, reciprocal differences were pooled and comparisons were made between all breed groups (table 4). Crossbred gilts tended to be younger at puberty than purebreds; the Yorkshire-Landrace and Yorkshire-Duroc crosses which were both older at puberty than Spotted and Landrace gilts were exceptions. The oldest gilts at puberty were the Duroc and Yorkshire purebreds, while the youngest were the DurocLandrace, Duroc-Spotted and the SpottedLandrace crossbreds. Significant differences were found only between the extremes.

A comparison of Yorkshire, Duroc, Landrace, Hampshire and Large White purebred gilts indicated that Landrace was the youngest at puberty and Duroc and Yorkshire the oldest (Christenson and Young, 1978). This agrees with the ranking of these purebreds in the present investigation. In addition, Duroc and Yorkshire purebreds were older at puberty than all other purebreds and all possible two-breed cross gilts involving Duroc, Yorkshire and Poland Chinas (Foote et al., 1956). No comparisons involving the Spotted breed were found. However, as Poland Chinas were utilized as a foundation breed during their development, Spotted and Poland Chinas might be expected to be similar. Poland China gilts mature earlier than Yorkshires (Foote et al., 1956; Clark et al., 1970) and Durocs (Foote et al., 1956). Thus, if Spotted and Poland Chinas are genetically similar with regard to pubertal characteristics the results in the literature would be in agreement with those from the present study since Spotted purebreds were younger at puberty than either Durocs or Yorkshires in this investigation.

Previous investigations comparing similar two-breed crosses were limited to crosses involving Duroc, Landrace and Yorkshire. DurocYorkshire and Yorkshire-Landrace had similar ages at puberty (200 and $202 \mathrm{~d}$, respectively), while the Landrace-Duroc were 16 and $18 \mathrm{~d}$ older at puberty than either the Duroc-Yorkshires and Yorkshire-Landrace crosses, respectively (Holtman et al., 1975). Differences between Duroc-Yorkshire and Yorkshire-Landrace cross gilts were also small in the present study $(.6 \mathrm{~d})$, however, the Duroc-Landrace was 13.2 and $13.8 \mathrm{~d}$ younger at puberty than the DurocYorkshire and Yorkshire-Landrace, respectively. These results disagree with regard to Yorkshire crosses that tended to be older at puberty; Holtman et al. (1975) found the Yorkshire crosses to be among the youngest breed groups at puberty.

Comparisons of all two-breed crosses involving Poland Chinas, Duroc and Yorkshire gilts indicated that Poland China crosses reached puberty earlier than the Duroc-Yorkshire cross (Foote et al., 1956). Results of this study indicate that Spotted-Duroc and SpottedYorkshire crosses were younger at puberty than the Duroc-Yorkshire; thus, these results are consistent with those of Foote et al. (1956) if Poland China and Spotted breeds are genetically similar with respect to pubertal characteristics.

No significant differences between Yorkshire, Landrace, Lacombe, Hampshire, Duroc and Large Black purebreds were found in weight at puberty (Fahmy et al., 1971). However, the ranking of the Duroc, Yorkshire and Landrace breeds was the same as in this study.

Evidence of differences among swine breeds in weight at puberty is limited, however, differences have been found between Chester Whites and Poland Chinas (Robertson et al., 1951a,b).

These data indicate the existence of breed differences in age at puberty. The results also demonstrate important heterotic effects upon age at puberty. These breed comparisons should be helpful in evaluation of the efficiency of production systems.

\section{Literature Cited}

Christenson, R. K. 1979. Influence of confinement and season on age at first estrus and estrous activity of gilts. J. Anim. Sci, 49 (Suppl. 1):114.

Christenson, R. K. and L. D. Young. 1978. Age at first estrus in five breeds of gilts reared in confinement. J. Anim. Sci. 47 (Suppl. 1):351.

Clark, J. R., N. L. First, A. B. Chapman and L. E. Casida, 1970. Age at puberty in four genetic groups of swine. J. Anim. Sci. 31:1032 (Abstr.).

Fahmy, M. H., C. S. Bernard and W. B. Holtman. 1971. Crossbreeding swine: Reproductive performance of 7 breeds of sows bred to produce crossbred progeny. Can. J. Anim. Sci. 51:361.

Foote, W. C., D. P. Waldorf, A. B. Chapman, H. L. Self, R. H. Grummer and L. E. Casida. 1956. Age at puberty of gilts produced by different systems of mating. J. Anim. Sci. 15:959.

Henderson, C. R. 1963. Selection index and expected advance. In: W. D. Hanson and H. F. Robinson (Ed.) Statistical Genetics and Plant Breeding. Pub. 982 pp 141-163. National Academy of Sciences-National Research Council, Washington, DC.

Henderson, C. R. 1973. Sire evaluation and genetic trends. Proc. of the Anim. Breeding and Genetics Symp. in Honor of Dr. Jay L. Lush. ASASADSA, Champaign, IL. p 10. 
Henderson, C. R., O. Kompthome, S. R. Searle and C. $M$. von Krosigk. 1959. The estimation of environmental trends from records subject to culling. Biometrics 15:192.

Holtman, W. B., M. H. Fahmy, T. M. Macintryre and J. E. Moxley. 1975. Evaluation of female reproductive performance of $\mathbf{2 8}$ one-way crosses produced from eight breeds of swine. Anim. Prod. 21:199.

Hubbard, D. D. 1976. Guidelines for uniform swine improvement standards. Program A, 01157 USDA Extension Service.

Hughes, P. E. and D. J. Cole. 1976. Reproduction in the gilt: 2 . Influence of gilt age at boar introduction on the attainment of puberty. Anim. Prod. 23:89.

Hutchens, L. K., R. L. Hintz and R. K. Johnson. 1981. Genetic and phenotypic relationships between pubertal and growth characteristics in gilts. $J$. Anim. Sci. 53:946.

Legault, C. 1973. Genetic analysis of sexual precocity, ovulation and number of embryos in the sow: Heritability, effect of heterosis. Journees de la recherche porcine en France. $p 147$.

Mavrogenis, A. P. and O. W. Robison. 1976. Factors affecting puberty in swine. J. Anim. Sci. 42: 1251.

Reutzel, L. F. and L. J. Sumption. 1968. Genetic and phenotypic relationships involving age at puberty and growth rate of gilts. J. Anim. Sci. 27:27.

Robertson, G. L., L. E. Casida, R. H. Grummer and A. B. Chapman. 1951a. Some feeding and management factors affecting age at puberty and related phenomena in Chester White and Poland China gilts. J. Anim. Sci. 10:841.

Robertson, G. L., R. H. Grummer, L. E. Casida and A. B. Chapman. 1951b. Age at puberty and related phenomena in outbred Chester White and Poland China gilts. J. Anim. Sci. 10:647.

Short, R. E. 1963. Influence of heterosis and plane of nutrition on reproductive phenomena in gilts. M.S. Thesis. Univ. of Nebraska, Lincoln, NE.

Zimmerman, D. R., P. Bourn and D. Donovan. 1976. Effect of "Transport Phenomena" stimuli and boar exposure on puberty in gilts. J. Anim. Sci. 42:1362.

Zimmerman, D. R., H. G. Spies, E. M. Riger, H. L. Self and L. E. Casida. 1960. Effect of restricted feeding, crossbreeding and season of birth on age at puberty in swine. J. Anim. Sci. 19:687. 